\title{
PRELIMINARY NOTES
}

Sites, towns and cities will be referred to in their Spanish name for quicker reference, excepting sites such as Lisbon or Seville, or geographical elements like the Tagus or the Pyrenees with overwhelmingly accepted English names. Latin terms and texts will be italicised, as well as texts inserted in other languages (translations provided in inverted commas). Whenever the Peninsula (with a capital P) is referred to, the Iberian Peninsula will be implied.

Unless specified, all figures and translations are the author's own work. All aqueduct maps have been drawn with QGIS on geographic data provided by the Geographical Institute of Spain (IGN); ancient coastlines and roads are based on and modified from the Barrington Atlas, and aqueduct courses derive from my previous research (Sánchez López and Martínez Jiménez 2016).

Before the final manuscript was sent to print, it was brought to my attention by Miquel Martí that the upper courses of the aqueduct of Valencia have been identified and mapped to a source in Tuéjar. This greatly improves our understanding of the aqueduct of Valencia and its source, but should not affect the chronological conclusions presented here.

\section{GLOSSARY}

Acequia

Alcázar, alcazaba

Balneum/balineum, -i

Caput, -itis [aquae]
Irrigation channel

Castle or palace of Arabic origin

Private/domestic baths

Source of the aqueduct

xi 
xii AQUEDUCTS AND URBANISM IN POST-ROMAN HISPANIA

Castellum divisorium/aquarum Terminal/distribution tank

Cuniculus, $-i$

Domus, $-\bar{u} s$

Fons, -tis

Hammam

Nymphaeum, - $i$

Opus, -eris

caementicium

quadratum

testaceum

sectile

signinum

Piscina limaria

Saqiya (= acequia)

Spiramen, -inis

Specus, -üs
Tunnel

Urban house

Fountain, spring

Baths

Monumental fountain

Mortared rubble

Ashlar masonry

Brick-faced mortar

Cut-marble inlaid floor

Water-proof mortar

Settling tank

Conduit or channel

Manhole

Conduit, usually inside the aqueduct 
Matri carae (†2OI2):

Mente igitur tali tamque alta praedita, inter maritum, gratos filios interque cognatos, omnibus illaesis morienti sensibus, altum obtulit illi animum dederat qui caelitus, ea nunc addat cum coelo gandiisque repleat almis; nempe sui memores reficit nos mortua heroina.

Adapted from Juan Hurtado de Mendoza (attrib.) I540 'Hyspana Georgii Manrrici Carmina', versio Latina of the 'Coplas' by Jorge Manrique. 
